\title{
The Individual Conflict in Lord Byron: Anthropological Reading
}

\author{
Norah Hadi Alsaeed ${ }^{1}$ \\ ${ }^{1}$ Aljouf University, Saudi Arabia \\ Correspondence: Norah Hadi Alsaeed, Aljouf University, Saudi Arabia. E-mail: nora.h.alsaeid@ju.edu.sa
}

$\begin{aligned} & \text { Received: October 13, } 2014 \\ & \text { Accepted: January 5, } 2015 \quad \text { Online Published: February 25, } 2015 \\ & \text { doi:10.5539/ells.v5n1p37 }\end{aligned} \quad$ URL: http://dx.doi.org/10.5539/ells.v5n1p37

\begin{abstract}
This paper sheds light on the individual conflict in Lord Byron's Don Juan in an anthropological cultural context. Despite some weakness in structure and form, and despite much mockery, seduction traits, Don Juan is a vast creation in its theme. Always self-conscious of his literary standing, Byron did not neglect to include literary and cultural criticism in this comedic epic. That is to say it is a satirical work in a comic style; it introduces the image of the present state of citizen. Hence it is so difficult to discuss the varied topics in Byron's Don Juan; this paper will concentrate on the image of citizen in the poem. The individual in Lord Byron's Don Juan must practice national identities, where practices of admittance and segregation can form and sustain boundaries and national character. It helps distinguish between homes and away, the uncertain or certain. It often involves the demonization and dehumanization of groups, which further justifies attempts to civilize and exploit these 'inferior' others. In this paper I try to shed some light on something that can almost never be expressed in words. Byron borrowed this truth from the epics of Virgil and Homer; the satire of François Marie Voltaire, Miguel de Cervantes, Alexander Pope, and Jonathan Swift; and the picaresque novels of Tobias Smollett, Henry Fielding, and Laurence Sterne. The result is a work satiric in tone, epic in scope, and harshly realistic in its portrayal of personal and national awareness.
\end{abstract}

Keywords: Lord Byron's, Seraglio, Gulbeyaz

Lord Byron is publicly praised as the fashionable, notorious and flamboyantartist among the great romantic poets. Their dynamism has primarily attracted the hearts and minds of more people and also their interest to give freedom for oppressed individuals in all places. Their work mostly personifies the Romanticism in their different shades. The popularity of the Bryon's poems had immensely create as a Romantic hero, commonly termed as Byronic Hero, who is haunted by secret guilt, sophisticated, defiant and free-thinking, although act as a fighter for freedom (Thorslev, 1962). Numerous critics observed Lord Byron personally acts as the model to leading the character; therefore, he is called as the Byronic hero. This paper attempted to shed light on individual conflicts that arises due to the cultural variations of characters portrayed in Lord Byron's Don Juan. Further this paper described the historical settings of Lord Byron's Don Juan. In this paper, I argue that Don Juan as poetic texts, literary commodity, and the cultural event. Don Juan who is a Byronic hero, their trends and attitudes are same to Byron (Therslev, 1962). He is proud, impulsive, arrogant, daring and passionate and also he is the important dramatic creation of Byron (Therslev, 1962). Moreover, he loved women, but he is not loyal to women.

Byron at the time of living in Greece and Turkey created the Eastern affinities which shaded their Eastern stories (Rishmawi, 1999), are yet felt in their later verse, specifically in their outstanding artistry. Even though the Eastern tales is the similar story of Don Juan, it pointed out the attitude of Byron toward Juan. As their one of the story part of Eastern tales described the Byron make a clear background and a powerful intention for their involvement as hero along with women and men in Eastern context, their participation as Byronic hero give way to him in revenge and violence, and endures the succeeding feeling of remorse and guilt. Then, the Eastern tales of Byron described the spiritual thoughts throughout his reputational years and intercepted him from going frantic. Byron's cultural involvement is centred on the Seraglio, corruption and the Eastern power symbol and also the more efficient Muslim East in the Western invention. The interest of Byron toward the Seraglio is in two levels such as: political and social. Through the social level aspect, Byron evidently revealed that the Seraglio inhabitants, the Sultan, his most lovable wife (Sultana Gülbeyaz), the eunuch, housekeepers, and discloses unreasonable examples that portray the connections exist between them, and also those why they have with the outside world. Such awkwardness is clearly observed in the sensational experience between Juan and Gulbeyaz, the Sultan's attitude to his numerous housekeepers and wives, and also the harem, which is the more reserved 
Seraglio wing. From the political aspect, Byron indicates the irresponsible in lustful and distinct Seraglio master and slightly critized himself for the unsuccessful for the attack of Ismail that leads to thousands of honest people's death occurred. In addition, the Seraglio supports Byron introduced his intense attack in opposition to tyrants and tyranny (in this situation, the Gulbeyaz and Sultan) (Rishmawi, 1999) who misapply the invested power into them through the mankind. Even, one need to recollect that Byron's constant battle against Turkish dictators does not avert him from acknowledging Turkish soldiers heroism and courage who pass on the home defence, and from Juan creation, as a hero to save the life of Leila, the Orphan child of Turkey. Indeed, Byron attains a moral impartiality in the big level in his aim of the Turkish City of Ismail. This provides the powerful inducement for blaming vain generals and aimless wars.

Before we debate the exposition of Byron in the complex seraglio social life, and his serio-comic, realistic andinhabitant's characters through the psychological analysis, this is vital to focus on the way in which Juan, Byron's hero, really go into the palace of Sultana - which is the reserved place for royal connections or background people or for the sultan's eunuchs and harem. Such happening takes us backward to slave market of Istanbul in which the Eastern context of Juan starts. Through the slave market of Istanbul, Juan is finally sold by Baba who is the royal eunuch who is not misspendingnumerous times in shifting their valuable freight to its terminus. Don Juan does not understand the reality; he entered into the sultana's palace. As he pushed roughly to the one corner place of the palace during the time he understood Baba's degrading job. According to Baba's threat of castration, Juan accepted to wear the Sultan's house maid dress. At the same dress, Juan ran away from the screening eyes of Gülbeyaz's bedroom gate keepers and lastly entered into the Gulbeyaz's room. Therefore, the encounter starts between Juan and Gulbeyaz. This is the experience that clearly revealed that sexual and social complexity incident occurred in the palace.

In an unexpected situation, important explanation beyond the dispute is love; both Juan and Gulbeyaz are different characters. Gulbeyaz, considers Juan is assert, command him to take her life. "Christian, canst thou love?" However, the Juan does not accept the order of Gulbeyaz and demands that love is only a free act. In addition, Juan triumphantly states that "even if tyrants enslave our flesh, our souls will remain free, and that love itself is a gift of freedom"

Our souls are free, and this in vain

We would against them make the flesh obey-

The spirit in the end will have its way. (CV Cx)

$* * * * *$

Love is for the free!

I am not dazzled by this splendid roof:

Whatever thy power and great is seems to be.

Heads bow, Knees bend, eyes watch around a throne

And hands obey- our hearts are still our own. (CV CXXVii)

One can consider there are two methods of interpreting disagree that arises between Juan and Gulbeyaz where the preferable rejects her sexual approach. Mcgann believes that the Juan appeared to trust the motto genuineness is "Love is for the free" (112) and also attributes the moral stand to their purity (113). Then Additionally, Gulbeyaz have not the ability to recognised the Juan, for the reason that Gulbeyazcomes under the customary procedure being a dictator, obeyed and heard and therefore she does not understood the moral of Juan.

This was a truth to us extremely trite

Not so to her, who ne'er had heard of such things

She deem'd her least command might yield delight

Earth being made of queens and kings. (CV CXXXViii)

Further, Juan personally involved in compromising their motto. It was evident the softening nature of Juan in their moral stand with crude sensuality of Gulbeyaz. From this first attack of Gulbeyaz is to command Juan make love with her, this command that are heavily differ strikingly in the mind of Juan with the beloved Haidee experience of idyllic island. As a result it proved the most colourful memories and severe pain by slavery, Juan cries and argued that Gulbeyaz owns their flesh, but does not their own spirit. Although, the Juan tears creates the moistening effect of Gulbeyaz eyes. 
And thus Gulbeyaz, though she knew not why,

Felt an odd glistening moisture in her eye (CV Cxx)

Gulbeyaz is yet situated on happening with her plans. Hence, she attacks Juan once more, this time by tossing herself wildly on him:

She rose, and pausing one chaste moment, threw

Herself upon his breast, and there she grew. (CV Cxxv)

However, he is yet perfect, regardless he trusts in the freedom of the heart. Politely, Juan accepts the Gulbeyaz and described that he does a thing of "a sultana's sensual Phantasy."

The Prison'd eagle will not pair, nor I

Serve a Sultana's sensual phantasy. (CV Cxxvi)

Still from the particular situation, changes occurred in some things. Gulbeyaz, who showed like this she lost her "imperial" qualityand appeal, at last looking to tears. Humorously, the miracle occurs due to the tears of Gulbeyaz, Juan, made set up his mind:

To be impaled, or quarter'ed as a dish

For dogs, or to be slain with pangs refined,

Or thrown to lions, or made baits for fish (CV Cxli)

Could not resist "a woman crying [!]"

But all his great preparative's for dying

Dissolved like snow before a woman crying (CV cxli)

Juan is accepting the command of Gulbeyaz as a miracle. But unfortunately Sultan came at this difficult situation! In this manner one can close by describing that the love concept of Juan is an act of the free will that might look heroic and romantic, a could be recognised amusingly, if not satirically. Manning studied the conflict experience between the Juan and Gulbeyaz, it describes the female submissiveness and weakness while male represents the authority and power (Maninng 19-55). Juan responds unfavourably to sexual advances of Gulbeyaz because during the love-game moment, Gilbeyaz act as man and Juan as women, Juanna. On the grounds that at that phase of the adoration diversion she is the man and he is the defenceless lady: Juanna. It is just when Gulbeyaz sobbed i.e., turned into a lady, that Juan started to yield and apologize for his boorish conduct. Also regardless of the possibility that the Sultan's sudden appearances keep Juan from polishing his masculinity, he in any event recaptures his certainty in his manliness that was seriously undermined by his ladylike "disguise".

Probably, one can go to a superior recognising of the sexual clash between Juan and Gulbeyazif one sees it inside a bigger setting, for that situation a connection that incorporates a comparative circumstance in the story, and especially in "The Corsair". Setting the sexual clash in such a connection will support grow our Byron's state of mind understanding around the predicament of compelling Eastern ladies begin to fall in love with infidels! Similarly, Gulbeyaz, Gulnare falls in love with Conrad based on their genoristy and kindness not their features.But both Gulbeyazand Gulnare are rejected by their lovers in western countries and they are moved in the position of devoted and helpless women. The indifference of Seyd made by frustration of Gulnare and dislikes their hateful marriage, it leads to utmost level slaughtering their spouse expert to spare their lover. . Anyhow in this manner, Gulnare appeared to have debilitated Conrad's manliness. That is the reason he responded coldly to everything she did to spare him. It was just when Gulnare's quality subsided and when she requested Conrad's love and pardoning that he stooped and remunerated her deliberations with a cold kiss!

In this particular moment, this is important to describe the sexual encounter of Gulbeyaz with Juan is depicted the complex character of Gulbeyaz. Truth be told, it impels the spectator to surprise to the characterization of Byronauthenticityof Gulbeyaz. This give shed light on Byron in the past days did not meet a genuine Sultana whereas in Turkey, basically on the grounds that he couldn't have admittance to the array of mistresses. Therefore, one might expect Byron's description of Gulbeyaz to be far expelled from unconvincing and actuality yet, to counterbalance his absence of particular contribution with a Sultana, Byron fuse his readings on the Seraglio's boss occupants and their conduct with his own particular encounters with English aristocratic ladies. Regularly Byron ventures his learning of the female character on the Turkish ladylike autocrat, and this why Gulbeyaz the ladies is more exact and engaging than Gulneyaz the despot. Additionally, Byron appears to say that, on a basic level, Gulbeyaz is much the same as whatever viable lady whose cold marriage and unconcerned spouse don't fulfil her passionate and sexual needs. Sadly, for Gulbeyaz, her most recent issue with Juan 
progresses made her understand that she is human as well. Byron minutely depicts and examines the conduct of the spurned lady and the opposing feeling which experience her brain. This kind of emotions is the consequence of disappointment of Gulbeyaz isnot understood in which way to adapt to the affair negative end.

Her first thought was to cut off Juan's head

Her second, to cut only his acquaintance

Her third, to ask him where he had been bred:

Her fourth, to rally him into repentance;

Her fifth, to call her maids and go to bed;

Her sixth, to stab herself; her seventh,

To sentence the lash to Baba: but her grand resource

Was to sit down again, and cry of course (CV Cxxxix)

In the tales of Byron, nonsensical reactions of Gulbeyaz to Juan's surprising dismissal, Byron accomplishes the largest score in striking tyrant Gulbeyaz imagines that Juan is assert and compelled to love her. In this aspect, Byron put his concept to the issue of Gulbeyaz when she attributes her absence of sensitivity and human sentiments to the way that she has not at all needed to impart them to anybody. Their imperial separation, Gulbeyaz's tyrants take over, the lady in wants to love and administer her conduct.

...having no equals, nothing which had e'er

Infected her with sympathy till now,

And never having dreamt what 'twas to bear

Augut of a serious, sorrowing kind, although

There might arise some pouting petty care

To cross her brow, she wonder'd how so near

Her eyes another's eye could shet to tear (CV xix)

Other significant part of Gulbeyaz, the enthusiastic lady, is her noticeably unreasonable association with her husband, the sultan. In spite of the fact that she should be a model to her house keepers and an image of faithfulness and chastity to her spouse, Gulbeyaz is opposite character. She finds in her spouse's age, other wives, and numerous maids a great reason to fulfil her appetite in sex from the marital cot. From this she abuses the Moral code of Turkish and even dangers her life by educating Baba to purchase her male slaves and ordered to hide them from the eyes of Sultan. Byron portrays Gulbeyaz in one of her most telling minutes; unable to delight in youth of Juan from the sultan's sudden appearance, Gulbeyaz lies by the side of her spouse, waiting for the minute to go her lover : At last one can observe that the treatment of Byron's in the complex character of Gulbeyaz is that of the gentle satirist. Even though he attacks the inhumanity, cruelly and selfishness Byron does that delicately and even thoughtfully! Steffan Claims "Byron's softening of his attack on Gulbeyaz' tyranny, suggests that Byron is more interested in developing the Satritic face in the seraglio episode than in analysing "the plight of the opposed individuals" (211).

The incident between the slave of Sultana and Sultana, Steffan noticed, "the dramatic analysis of despotic character accentuates its disagreeable arrogance, jeers at its absurdities, but at the same time refrains from taking too seriously the plight of the oppressed individual. The cause of liberty is maintained and the vices of tyranny reproved, but the main actors and their conflict stay within the confines of satiric farce." (211) Byron efficiently utilizes sudden appearance of sultan at the bedroom of Gulbeyaz to move Juan (now termed as Juanna) into the Oda (where the servants rest), and in addition to criticism the sultan himself. Truly, among the inhabitants of seraglio, Sultan is the least, captivator and Byron does not lost an opportunity to laugh at his shallow-mindedness and stupidity. Steffan appropriately portrays the Sultan as "a buffo character, too absurd an autocrat to be other than a harmless nincompoop" (214). However, this is vital to make it clear right now that the intention of Byron in the sixth canto and harem episode goes beyond breaking points of being the "enormous joke" which Steffan attributes to it (212). It demonstrates Byron's psychologically deep understanding and the sympathetic nature of the secretive wing of the Seraglio inhabitants.In the Gulbeyaz case, Byron makes up for his absence of direct encounter in the Oda, by compelling description and vividof the housekeepers, the haremcaged women. Byron clearly noticed these women's behaviour. He effectively finds their fear, restlessness, and despair of the future. Byron suitably contrasted the servants with confined fledglings, however dissimilar to the feathered creatures, 
which beat for air, the housekeepers beat for the love of man, the insatiable sultan: Back to their chamers, those long gallieries

In the Seraglio, where the ladies lay

Their delicate limbs; a thousand bosoms there

Beating for love, as the caged birds for air. (CVI XXVi)

Generally, interest of Byron toward Don Juan is not constrained to the explanation of the complex and difficult sexual / sociallife in the seraglio. The impact of Seraglio is felt outside its mystery galleries and strikingly in the battlefield among the Russians and the Turksover the Ismail, a Turkish city. Furthermore, Byron's fairness is reflected in his deference of the genuine bravery of the Tartar Khan who dies with regards to his home, and his nausea at the Turkish Pasha who recklessly smokes his channel and weak Russians surrenders. Byron sees the khans as he seems to be: not "a Priam's Peleus' or Jove's child, "but a good plain, old, temperate man who fought with his five children in the Van" (CVicv). Therefore, we can see that Byron does not censure all Turks as a result of the conduct of the Turkish Pasha. Indeed, he makes a spot for the Tartar Khan among the legends of traditional Western custom. This is a confirmation of Byron's comprehendsand tolerance of the benefits that settle on society equivalent and his choice not to take after the generalization of the Muslim East as a position of a substandard society.

In conclusion, one can say that although Byron depicted various themes are mentioned in Don Juan but Byron could be able to represent a tolerable image and humours of the East, this representation could leads to familiar in both East and Western countries depicted as wit of poet. Moreover, one can understood the attitude development of Byron to the East culture by their important analysis of Gulbeyaz complex nature. In this story, there is no specification of Byron so profoundly dove in the heart and mind of a strong woman in the East and depicted the contradictory feelings and the feminine nature of Juan with Gulbeyaz. Gulnare, passionate and strong is not engaging as Gulbeyaz, basically because Byron, in portraying character of Gulbeyaz has at last put "acid scrutiny of common sense" (Rutherford, A critical study 45) (Blackstone, 1975)

\section{References}

Blackstone, B. B. (1975). A Survey. London: Longmans \& Roberts.

Rishmawi, G. K. (1999). The Muslim East in Byron's Don Juan. Papers on Language \& Literature, 35(3).

Therslev, P. L. (1962). The Byronic hero: Types and prototypes. US: the University of Minnesota.

Thorslev, P. L. (1962). The Byronic Hero: Types and Prototypes. Minneapolis: Collier.

\section{Copyrights}

Copyright for this article is retained by the author(s), with first publication rights granted to the journal.

This is an open-access article distributed under the terms and conditions of the Creative Commons Attribution license (http://creativecommons.org/licenses/by/3.0/). 